\title{
A REVISION OF NEW WORLD BRONTAEA KOWARZ (DIPTERA, MUSCIDAE) ${ }^{1}$
}

\author{
Claudio José Barros de Carvalho ${ }^{2}$ \\ Adrian Charles Pont ${ }^{3}$
}

\begin{abstract}
Five species of Brontaea Kowarz (=Gymnodia Robineau-Desvoidy, preocc.) occur in the New World. B. humilis (Zetterstedt) has been introduced from Europe and is known from a few localities in eastern and Pacific coast Canada and USA. B. normata (Bigot) is an endemic Neotropical species. The other species, $B$. debilis (Williston), B. quadristigma (Thomson) (=cilifera Malloch, syn.nov.) and $B$. delecta (Wulp) (=arcuata Stein) occur throughout warm and temperate areas of the Americas. They are common filth flies, and are frequently collected in faeces-baited traps. Brontaea is probably a polyphyletic genus. The species discussed here appear to be correctly placed in the subfamily Mydaeinae. An identification key, descriptions, illustrations and geographic distribution are given for all five species.

KEY WORDS. Brontaea, distribution, habits, New World, taxonomy.
\end{abstract}

The genus Brontaea Kowarz is probably polyphyletic. Some species have a "Phaonia-type" of ovipositor, whilst others have a "Mydaea-type". All the species dealt with in this paper have an ovipositor of the "Mydaea-type", and furthermore B. humilis (Zetterstedt, 1860) has eggs of the "Mydaea-type" sensu SKIDMORE (1985). We are provisionally transferring the genus to the Mydaeinae, as was previously suggested by CARVALHO (1989), and will be undertaking further study of the world species in order to resolve the polyphyly of this genus.

Of the five species that occur in the New World, it seems that only B. normata (Bigot, 1885) is endemic to the Neotropical region. Three of the remaining four species, B. debilis (Williston, 1896), B. delecta (Wulp, 1896), B. quadristigma (Thomson, 1869), occur throughout the Americas, whilst B. humilis appears to be a relatively recent introduction from Europe into North America.

Adults are commonly found around cow dung, in which the larvae breed, but they are also attracted to other excrement including that of humans and to garbage: they are common and important members of the filth-fly community.

1) Contribuition number 726 of the Departamento de Zoologia, Universidade Federal do Paraná.

2) Departamento de Zoologia, Universidade Federal do Paraná. Caixa Postal 19020, 81531-990 Curitiba, Paraná, Brasil. CNPq fellow.

E-mail: cjbcarva@bio.ufpr.br.

3) Hope Entomological Collections, University Museum. Parks Road, Oxford, OX13PW, UK. 
Abbreviations for the museums and institutions where material is located are:

BMNH - The Natural History Museum, London, UK; CNC - Canadian National Collection of Insects, Arachnids and Nematodes, Ottawa, Ontario, Canada; DZUP - "Departamento de Zoologia, Universidade Federal do Paraná", Curitiba, Brazil; FMNH - Field Museum of Natural History, Chicago, Illinois, USA; IMZ "Instituto e Museo di Zoologia", University of Turin, Italy; INHS - Illinois Natural History Survey, Urbana, Illinois, USA; MNRJ - "Museu Nacional do Rio de Janeiro", Rio de Janeiro, Brazil; MZSP - "Museu de Zoologia da Universidade de São Paulo", São Paulo, Brazil; NMWC - National Museum of Wales, Cardiff, UK; NRS - "Naturhistoriska Riksmuseet", Stockholm, Sweden; UMO - Hope Entomological Collections, University Museum, Oxford, UK; USNM - National Museum of Natural History, Washington, DC, USA; ZMHU - "Zoologisches Museum der Humboldt-Universität”, Berlin, Germany.

Terminology and most abbreviations for characters follow MCALPINE (1981).

\section{Brontaea Kowarz, 1873}

Gymnodia Robineau-Desvoidy, 1863:635. [Junior homonym, preocc. by Gymnodia Robineau-Desvoidy, 1830.] Type-species: Gymnodia pratensis Robineau-Desvoidy, 1863 [=Anthomyia polystigma Meigen, 1826], by monotypy.

Brontaea Kowarz, 1873: 461. Type-species: Anthomyia polystigma Meigen, 1826 (des. by Coquillett, 1910: 516).

Brachiophyra Giglio-Tos, 1893: 9. Type-species: Brachiophyra effrons Giglio-Tos, 1893 [=Limnophora normata Bigot, 1885], by original designation.

Brachyophyra, erroneous subsequent spelling.

Eulimnophora Malloch, 1920: 145. Type-species: Limnophora arcuata Stein, 1898 [=Limnophora delecta Wulp, 1896], by original designation.

Diagnosis. New World species of Brontaea may be recognized by the presence of stiff marginal setulae at the sides of abdominal sternite l (Fig. 26). They also have abdominal sternite 2 partly to mainly shining, with the setulae confined to lateral and/or posterior margins.

In other New World Muscidae with abdominal sternite 1 setulose, the setulae are finer and more hair-like, and are usually arranged along the whole sternite rather than confined to the sides.

Description. Male head holoptic, female head dichoptic. Female frons without proclinate orbitals and without crossed setae on frontal vitta. Arista bare, i.e. the longest hairs not equal to its basal diameter. Dc 2:4. 1-2 post ia. Pra absent. 1 ipal. Disc of notopleuron bare. Postalar declivity, suprasquamal ridge, prosternum and proepisternal depression bare. 1 proepisternal and 1 proepimeral seta present. Anepisternum with a short seta in upper anterior corner. Anepimeron, greater ampulla, vallar ridge, and meron bare. Ktps 1:2. Metathoracic spiracle small, triangular, bare on margins. Mid femur without $\mathrm{A}$ and $2 \mathrm{P}$ preapical setae. Mid tibia with 1 submedian $P$ seta; 1 strong $V$ apical setae. Hind tibia without calcar, with 1 short submedian AD; D apical seta strong, AD and PV apicals absent. Veins bare, 
except for costa. Vein $\mathrm{M}_{1+2}$ straight or curved slightly forward towards vein $\mathrm{R}_{4+5}$ in apical part. Lower calypter of the "Phaonia-type", bare. Sternite 1 with stiff setulae at sides (Fig. 26). Male aedeagus simple, epiphallus well-developed [not reduced as in the Australian species - see PONT (1977)], juxta wholly membranous (Figs 36, 38, 41, 43, 45, 46). Female ovipositor of the "Mydaea-type", as in Figs 47-51; 3 spermathecae. Eggs of the "Mydaea-type" (SKIDMORE 1985).

\section{Previous cladistics analysis}

We are in the process of making a cladistic analysis of the subfamilies and tribes of world Muscidae. Our analysis, based on 80 characters, has included 7 species of Mydaeinae, 15 of Limnophorini and 26 of Coenosiini, as well as 3 species of Brontaea (B. humilis, B. debilis, B. quadristigma). We used Hennig 86 for this analysis. Cladograms (trees) were generated with $\mathrm{mh}^{*}$; bb*. All character state were treated as unordered and successive weighting procedure (xsteps $\mathrm{w}$; in combination with $\mathrm{mh}^{*} ; \mathrm{bb}^{*}$ until no longer change). After the nelson consensus tree was produced by nelsen comand. On one occasion Brontaea appeared as the sister-group of the entire Coenosiinae, and Brontaea + Coenosiinae as the sister-group of one section of a paraphyletic Mydaeinae. On all sther occasions, Brontaea nested in the Mydaeinae, which generally emerged as monophyletic, and often as the sister-group of the genus Hebecnema Schnabl. Hebecnema and Brontaea have the pre-alar seta absent, a synapomorphy within the Mydaeinae.

SKIDMORE (1985), in his study of the immature stages, erected a tribe Brontaeini for the genera Brontaea, Scenetes Malloch, Hennigiola Pont and Prohardyia Pont. He provisionally assigned it to the Phaoniinae, but commented: "The Brontaeini [have] more features in common with the Mydaeinae." Our conclusion is that the genus Brontaea, or at least the five species dealt with in the present paper, should be transferred to the Mydaeinae.

The genus occurs in all biogeographic regions, but is absent in New Zealand and Oceania (but introduced into Hawaii). Adults and larvae are closely associated with the excrement of ruminants, particularly of cattle and horses.

\section{Key to the New World species of Brontaea Kowarz}

1. Anterior post ia seta present and very strong, at least as long as the posterior seta. Male: scutum almost entirely dark brown dusted, without vittae (Fig. 3); calypters dark brown; outer rows of prst acr setulae at suture closer to each other than to dc; parafacial sunken, mostly obscured by eye in lateral view; abdomen with dark markings as in figure 8 ; cercal plate as in figure 40 . Female. Ovipositor as figure 49, sternite 7 present as a short rod. Canada and USA (BC and states around the Great Lakes); Palaearctic region ......... humilis (Zetterstedt)

- Anterior post ia seta reduced or absent, rarely even half as long as the posterior seta. Male: scutum extensively grey to yellowish-grey dusted and usually with distinct darker vittae; calypters creamy to yellow; outer rows of prst acr setulae at suture not markedly closer to each other than to dc; parafacial not sunken and visible in lateral view (except B. quadristigma); abdominal 
pattern and cercal plate different. Female: sternite 7 reduced to 1 or 2 tiny plates or bristle-dots (except B. quadristigma) . ............... 2

2. Scutum with dark vittae strong, very conspicuous and well-defined (Figs 4, 14). Palpi black. Male: outer rows of prst acr setulae equidistant between the dc and each other (Fig. 24); scutum with the dark central vitta continuing on to scutellum; abdomen with the dark markings on tergite 3 L-shaped (Fig. 9); cercal plate quadrate (Fig. 42). Female: sternite 2 wider than long. Central and South America, and West Indies ..............normata (Bigot)

- Scutum with dark vittae absent or, when present, not well marked and not sharply defined (Figs 1, 2, 5, 11, 12, 15). Male: outer rows of prst acr setulae usually closer to the dc than to each other (Figs 21, 22, 25); scutum with the dark central vitta discontinued at scutellum or continuing as an ill-defined and suffused mark; abdomen with the dark markings on tergite $3 \mathrm{~L}$-shaped or quadrate (Figs 6, 7, 10); cercal plate not as above .............. 3

3. Palpi yellow, darkened only at tip; larger species, body-length $4.6-6.7 \mathrm{~mm}$ but only rarely less than $5.0 \mathrm{~mm}$ (a few female specimens); knees broadly yellow, especially on fore leg; anterior post ia seta reduced or absent, hardly distinct from a ground-setula. Male: abdomen extensively yellow on basal segments, and the dark markings quadrate especially on tergite 3 (Fig. 6); cercal plate heart-shaped (Fig. 35); epiphallus abruptly enlarged apically, in dorsal view expanded mushroom-shaped (Fig. 36). Female: frontal triangle yellowishgrey dusted, very well marked; sternite 2 longer than wide. Southern USA, West Indies, Central and South America ............ debilis (Williston)

- Palpi black; smaller species, body-length $2.6-5.3 \mathrm{~mm}$; knees only narrowly or not at all yellow. Male: abdomen wholly black, the dark markings on tergites 3 and 4 as in figures 7, 10; cercal plate and epiphallus not as above. Female: frontal triangle dull grey to grey, less well marked .............4

4. Cross-vein dm-cu more or less straight; tergite $1+2$ narrowly grey dusted along hind-margin; sternite 2 wider than long, with 4-6 setulae placed on apical margin; anterior post ia seta very short, at most twice as long as a groundsetula. Male: ocellar setae very short, hardly longer than length of ocellar tubercle; 3-4 frontal setae; parafacial sunken, in lateral view partly obscured by eye; hind femur with 3-4 strong AV setae preceded by a series of much shorter but distinct setae along basal part of this surface (Fig. 27); cercal plate expanded at base and narrowing suddenly in apical part (Fig. 37); distiphallus without spinules on basal part (Fig. 38). Female: proepimeral seta with 0-1 adjacent setulae; fronto-orbital plate with 1-3 setulae outside lower frontal setae; tergites 4 and 5 with fewer, smaller and sparser brown bristledots; sternite 7 present as a short rod. USA (mainly southern states), West Indies, Central and South America ........... quadristigma (Thomson)

- Cross-vein dm-cu distinctly curved; tergite $1+2$ mainly dusted, narrowly black at base; sternite 2 longer than wide, with numerous setulae (usually 15-20) on lateral and apical margins; anterior post ia seta longer, at least twice as long 
as a ground-setula, often longer. Male: ocellar setae long and strong, at least equal to lowest frontal seta; 5-6 frontal setae; parafacial not sunken, visible in lateral view; hind femur with only the 3-4 strong AV setae in apical third (Fig. 29); cercal plate narrowing uniformly from base to apex (Fig. 44); distiphallus with spinules on basal part (Figs 45, 46). Female: proepimeral seta with 3-6 adjacent setulae; fronto-orbital plate with 4-6 setulae outside lower frontal setae; tergites 4 and 5 with numerous large brown bristle-dots; sternite 7 present only as 2 bristle-dots. Canada, USA, West Indies, Central and South America; Hawaii . . . . . . . . . . . . . delecta (Wulp)

\section{Brontaea debilis (Williston, 1896)}

Figs $1,6,11,16,21,26,30,35,36,47$

Limnophora debilis Williston, 1896: 369. - Aldrich, 1905: 547. - Huckett, 1932: 54. - Roberts, 1934: 253. - Séguy, 1937: 262 (cat.). - Garcia, 1964: no page.

Fannia? debilis; Stein, 1919: 131 (cat.).

Eulimnophora dorsovittata Malloch, 1920: 146.

Gymnodia scatophaga Curran, 1938: 5; Pont, 1972: 24 (cat.).

Gymnodia debilis; Huckett, 1965b: 884 (cat.). - Pont, 1972: 24 (cat.). - Capriles \& Navarro, 1971:57. - Gregor, 1975: 58. - Blume, 1986: 220.

Gymnodia arcuata; Wharton \& Moon, 1979: 85 (misidentification).

Brontaea debilis; Skidmore, 1985: 431. - Carvalho, 1989: 647 (generic classification). - Mendes \& Linhares, 1993:290 (Brazil). - Carvalho et al., 1993: 85 (cat.).

Types. Limnophora debilis: Described from 2 male, but only one syntype is now in the BMNH. This male is here designated as lectotype. It is labelled as "syntype"; "St. Vincent, / W.I. / H.H. Smith"; "W. Indies / 1907-66"; "Limnophora / debilis / Will." [handwritten label]. It is in good condition, with only mid tibia and tarsi missing and left wing broken in the costal region. The second syntype male appears to be lost.

Eulimnophora dorsovittata: Holotype female from Kingston, Jamaica, is in INHS (WEBB 1980) [not seen].

Gymnodia scatophaga: The holotype male and 1 male 2 female paratypes (one labelled as allotype) are in the BMNH. The holotype is labelled as "Holo-type"; "Reared fr. / cow dung / Haiti / Myers 6202"; "Gymnodia / scatophaga / Curran male / Holotype [handwritten red label]. It is in good condition. The paratypes are labelled as "Reared fr. / cow dung / Myers 6094 [female] or 6101 [male]. They are also in good condition. Two paratypes have puparia glued to their labels. We had dissected the genitalia of the holotype and can confirm the synonymy with $B$. debilis.

Diagnosis. B. debilis is the largest New World Brontaea species. It differs from the other New World species by the mainly yellow palpi and by the colour and pattern of scutum and abdomen. The male has an unique epiphallus which is enormously enlarged and mushroom-shaped in dorsal view.

Description. Male. Head. Frons slender, at narrowest point almost obliterated and visible only as a seam. Eyes with only the normal pubescence, upper inner facets enlarged as usual but not conspicuously so. Ocellar setae well developed, subequal to lowest frontals. Fronto-orbital plate, parafacial, face and gena silvery-white, more 
grey on lower part of head. Lunula yellowish, silvery-white pollinose. Fronto-orbital plates slender, each one equal to twice diameter of anterior ocellus. 6-8 pairs of short inclinate frontals on lower half of frons. Antenna black; flagellomere 2.6 times as long as broad, in frontal view falling short of epistoma by 0.7 of its length. Parafacial slender, opposite insertion of arista equal to 1.5 times diameter of anterior ocellus; not sunken. Parafacial and gena bare. Gena below lowest eye margin equal to width of antennal flagellomere. Prementum of proboscis short, dark brown dusted. Palpi slender, yellow except at tip.

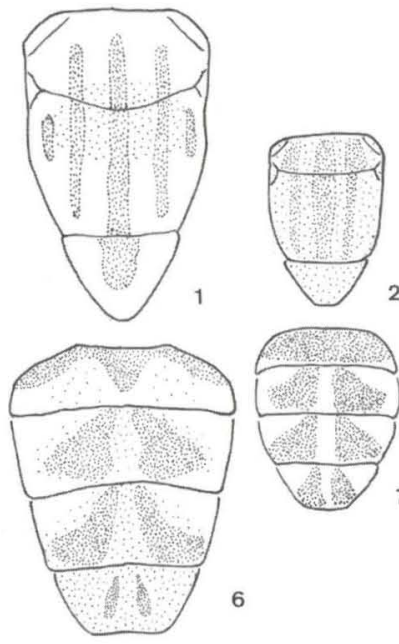

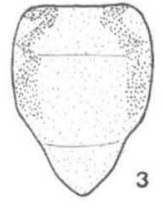
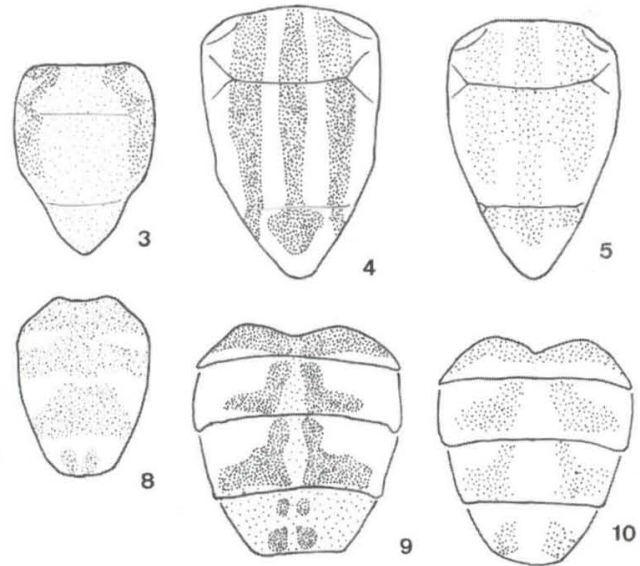

Figs 1-10. (1-5) Pattern of male scutum of Brontaea species: (1) debilis; (2) quadristigma; (3) humilis; (4) normata; (5) delecta. (6-10) Pattern of male abdomen of Brontaea species: (6) debilis; (7) quadristigma; (8) humilis; (9) normata; (10) delecta. Scale=2mm.

Thorax. Ground-colour black, entirely grey to yellowish-grey dusted. Scutum with 5 distinct but not always well defined dark brown vittae, the median one broadest and extending from neck on to scutellum where it is often very large, each paramedian pair connected behind suture by a small patch of brown dust (Fig. 1). Mesothoracic spiracle yellowish and metathoracic dark brown. Acr 0:1; prst setulae in 3-4 rows, outer rows at suture much closer to de than to each other (Fig. 21); post setulae in 4 rows. 2 strong pprn, sa 1:1, ia 1:1, anterior post ia reduced to a setula, 2 pa. 2 subequal npl setae. Anterior and lower ktps fine. Scutellum with 1 strong pair of apical and subbasal lateral setae; disc with setulae, these not descending below level of the strong setae, bare laterally and ventrally.

Legs. Black, knees broadly yellow. Tarsi unremarkable. Fore femur with complete rows of PV, D and PD setae. Fore tibia without submedian setae. Mid femur with 4-6 short PV setae in basal half, not equal to femoral depth; 7-9 fine A setae in basal half. Hind femur with 2-3 AV setae in apical third; AD row complete; with $1 \mathrm{D}$ and 0 PD preapical setae. Hind tibia with 1 submedian AV seta, subequal to median $\mathrm{AD}$. 

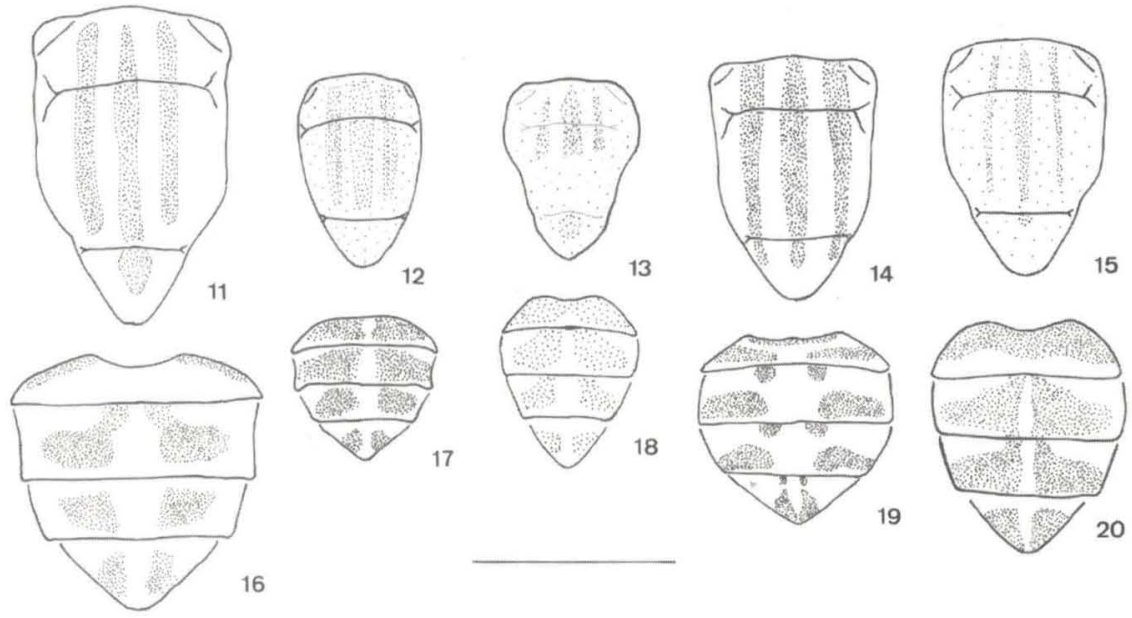

Figs 11-20. (11-15) Pattern of female scutum of Brontaea species: (11) debilis; (12) quadristigma; (13) humilis; (14) normata; (15) delecta. (16-20) Pattern of female abdomen of Brontaea species: (16) debilis; (17) quadristigma; (18) humilis; (19) normata; (20) delecta. Scale=2mm.

Wings. Clear to weakly smoky, veins yellow. Membrane entirely covered with microtrichia. Tegula black, basicosta orange to brown. Crossvein r-m placed below or just before point where vein $\mathrm{R}_{1}$ enters costa. Crossvein dm-cu oblique, weakly curved. Calypters yellowish, lower calypter often brownish in apical part. Halteres creamy to yellow.

Abdomen. Ground-colour mainly yellow, base of tergite $1+2$, most of tergite 4 , and tergite 5 except hind-margin black. In posterior view densely yellowish-white dusted, becoming grey behind; tergite $1+2$ wholly dusted; tergites 3 and 4 each with a pair of black markings, sometimes reduced to L-shaped spots on tergite 3 and oval hind-marginal spots on tergite 4 ; tergite 5 with 1 or 2 pairs of dark diffuse spots, sometimes elongate and sometimes absent (Fig. 6). Tergites without strong setae. Sternite 1 as figure 26.

Genitalia. See figures 30, 35, 36. 8 dissections.

Measurements $(n=40)$. Length of body, $5.4-6.7 \mathrm{~mm}$. Length of wings, 4.9 $-6.2 \mathrm{~mm}$.

Female. Differs from the male as follows:

Head. Frons broad, broadening gradually from vertex to lunula, at lunula 0.38-0.39 of maximum head-width. Upper inner eye facets not at all enlarged. Incurved vti and outcurved vte strong, subequal; pvt fine, outcurved. Fronto-orbital plate, parafacial, face and gena grey pollinose, the former tinged with yellow, and even brown at vertex. Frontal vitta matt black. Frontal triangle yellowish-grey dusted, reaching lunula. Fronto-orbital plate quite broad, broadening gradually from vertex to lunula, at vertex a plate almost twice diameter of anterior ocellus, at lunula equal to width of antennal flagellomere. Frontal vitta broad, narrowing to lunula where it is slightly broader than a fronto-orbital plate. 5-7 pairs of inclinate frontals 
on lower $2 / 3$ of frons; 2 orbitals, directed backwards and slightly outwards; fronto-orbital plate with several setulae. Parafacial slender, opposite insertion of arista equal to twice diameter of anterior ocellus, gradually tapering below.
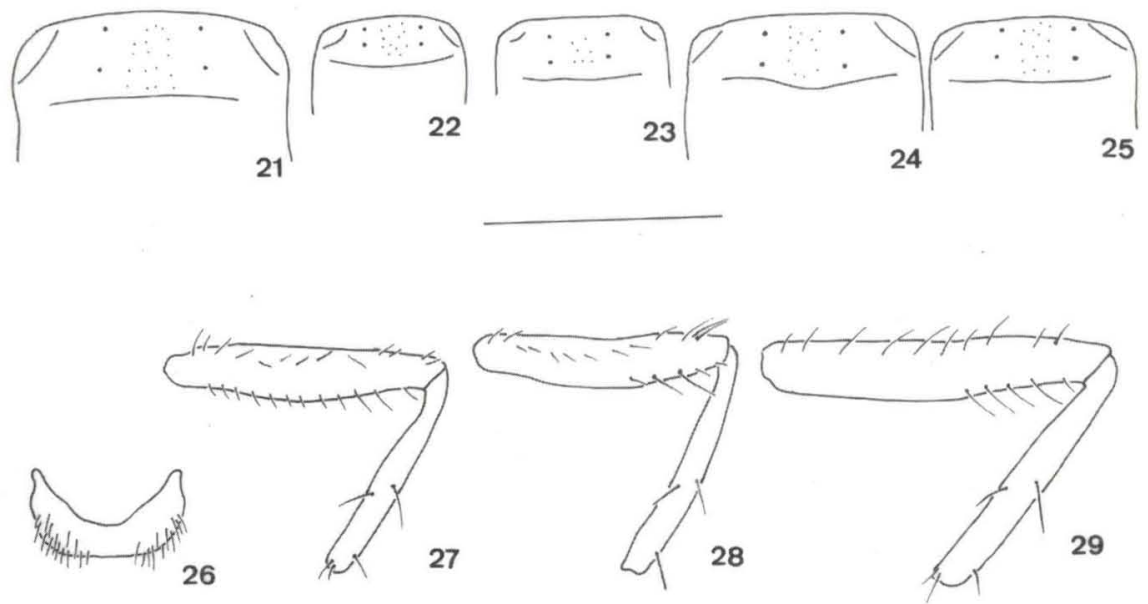

Figs 21-29. (21-25) Male presutural acrostichal and dorsocentral setae of Brontaea species: (21) debilis; (22) quadristigma; (23) humilis; (24) normata; (25) delecta. Scale=2mm. (26) Brontaea debilis, sternite 1, dorsal view. (27-29) Left hind femur and tibia of Brontaea males: (27) quadristigma; (28) humilis; (29) delecta. Scale=1mm.

Thorax. Scutum with the vittae distinct but narrower than in male, and often rather poorly defined (Fig. 11).

Wings. Clear. Calypters and margins wholly yellowish-white.

Abdomen. Entirely black in ground-colour. Tergites with dense grey dust, tinged with yellowish posteriorly; tergite $1+2$ without dark markings; tergites 3 and 4 with the dark markings larger, quadrate; spots on tergite 5 larger. Setae sparse and short.

Ovipositor. See figure 47.8 dissections.

Measurements $(n=66)$. Length of body, $4.6-6.2 \mathrm{~mm}$. Length of wings, 4.1 $-5.7 \mathrm{~mm}$.

Distribution. Extreme southern USA (Florida, Texas), Mexico, Honduras, West Indies (Grand Cayman, Jamaica, Haiti, Dominican Republic, Puerto Rico, St Vincent), Ecuador, Peru, Bolivia, Venezuela, Brazil, Argentina.

Biology. Adults have been collected on cattle and on fresh cow dung. The adult habits and immatures stages have been described by WHARTON \& MOON (1979), SKIDMORE (1985), and BLUME (1986).

Material examined. USA, Texas: Dallas, 23.VIII.1907 (FC Pratt Collection), 1 female (USNM); ibidem, 26.X.1907 (FC Pratt Collection), 1 male (MNRJ); 


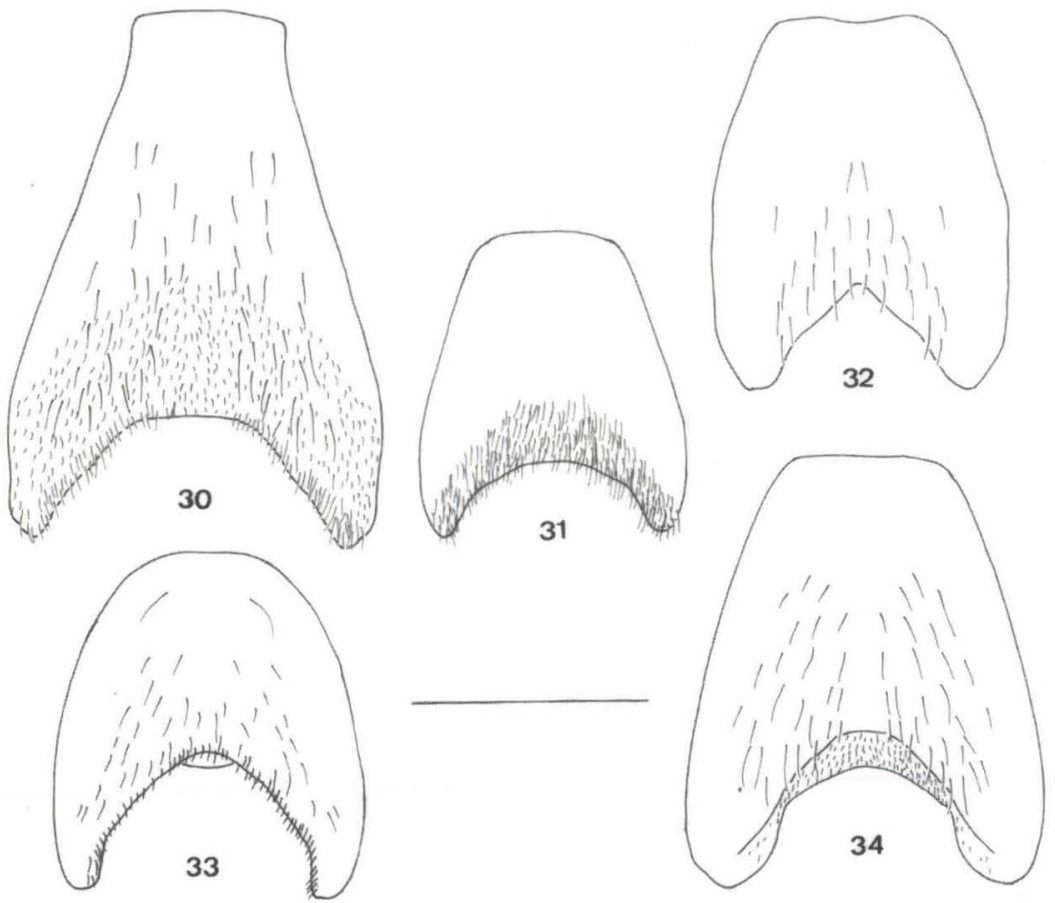

Figs 30-34. Male 5th sternite of Brontaea species. (30) debilis; (31) quadristigma; (32) humilis; (33) normata; (34) delecta. Scale $=0.5 \mathrm{~mm}$.

ibidem, 1.XI.1907 (FC Pratt Collection), 1 male (USNM); Florida: Marion Co., Bellevue, Hwy 27, 13.V.1967 (B.V. Peterson), 1 female (CNC); Ft. Ogden, 9.IV.1952 (J.R. Vockeroth), 1 female (CNC). MEXICO, Durango: Rio Chico, 20 miles W of Durango, 7000 feet, 10.VIII.1964 (J.F. McAlpine), 1 male, 3 females (CNC); 5 miles W of Durango, 6500 feet, 29.VI.1964 (J.F. McAlpine), 1 female (CNC); ibidem, 22.VII.1964 (J.F. McAlpine), I female (CNC); Veracruz, Lake Catemaco, 15.VI.1969 (B.V. Peterson), 1 male (CNC); Veracruz, Tierra Blanca, 500 feet, 15.VIII.1962 (H.E. Milliron), 1 female (CNC); Gro., El Ocotito, 40005000 feet, 20.VII. 1962 (H.E. Milliron), 1 female (CNC); S.L.P., 46 miles N of San L. Potosi, 1.IX.1958 (H.F. Howden), 1 female (CNC). HonduraS, San Marcos: Chol, 29.VII.1958 (Neff \& Matthews), 1 female (CNC). GRAND CAYMAN: Georgetown, Malaise trap, 15-30.III.1965 (J.R. McLintock), 1 male (CNC). JAMAICA: Windsor, 4.VII. 1957 (J.W. Boyes), 1 female (CNC). HAITI: reared from cow dung (Myers), 1 male, 6 females (BMNH). Dominican Republic: La Combre (P. Plata), 21-24.III.1978 (L. Masner), 1 male, 1 female (CNC). EcuAdor, Galapagos: San Cristoval, 560 m, 19.II.1989 (B.J. Sinclair), (CNC); Loja Dept., San Pedro, W of Catamayo, desert area, 1500 m, 7-8.IV.1965 (L. Peña), 1 male (CNC). Peru, Cuzco: Quincemil, 780m, 13-3 (CNC). VeneZUela: Caripe, 1000m, Malaise trap, 19.V.1973 (J. Shuttleworth), 3 males (CNC). BRAZIL, Roraima: Pacaraima, 5- 

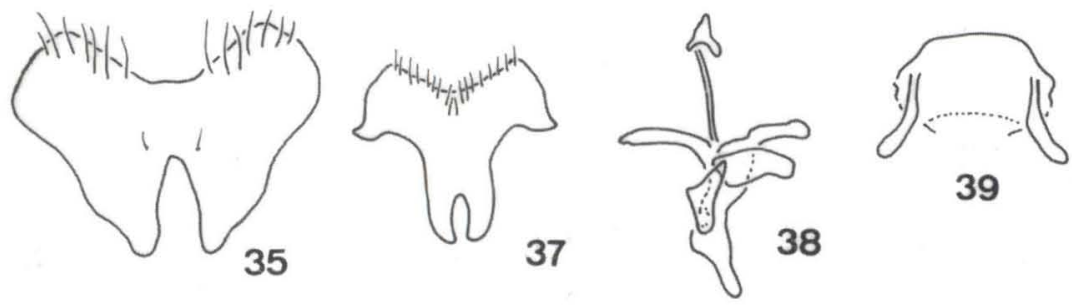

39
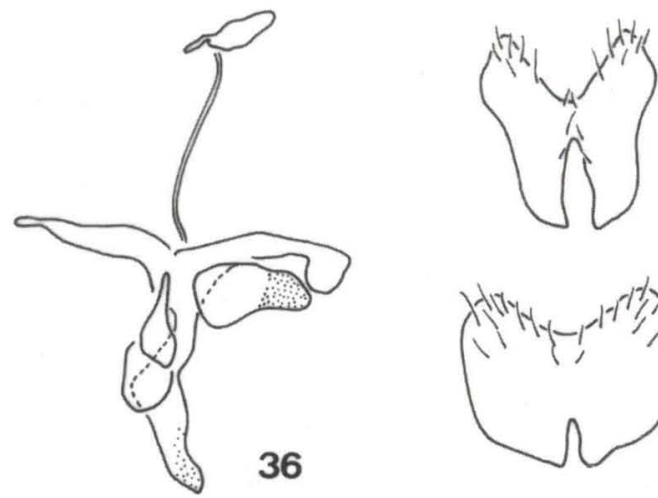

40
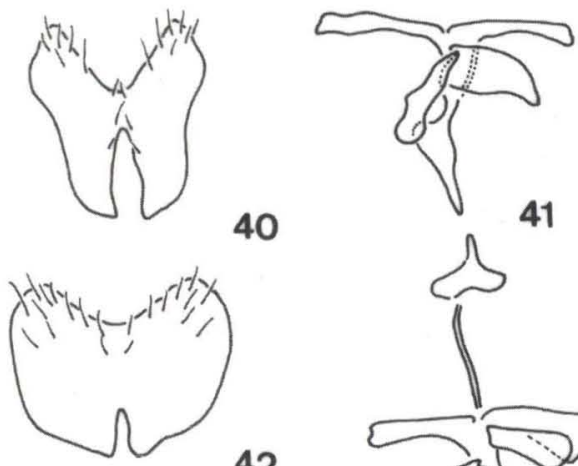

42
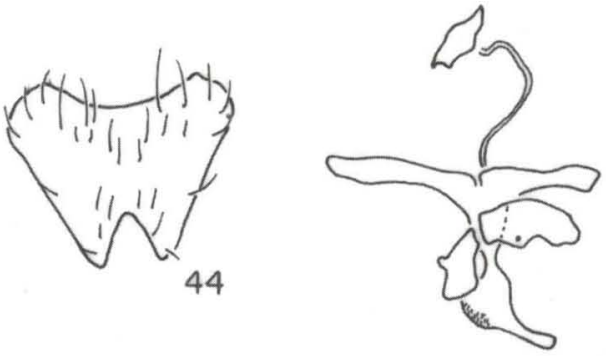

45

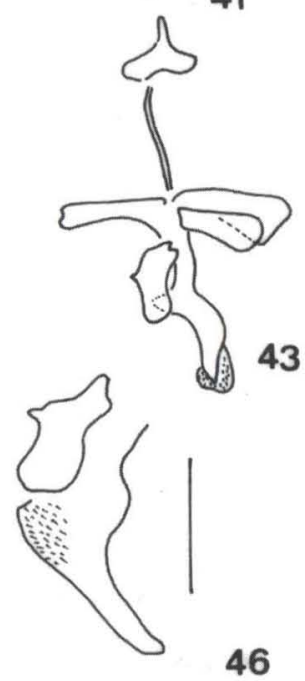

Figs 35-46. Male genitalia of Brontaea species: (35) debilis, cercal plate; (36) debilis, aedeagus; (37) quadristigma, cercal plate; (38) quadristigma, aedeagus; (39) quadristigma, hypandrium; (40) humilis, cercal plate; (41) humilis, aedeagus; (42) normata, cercal plate; (43) normata, aedeagus; (44) delecta, cercal plate; (45) delecta, aedeagus, (46) delecta, detail of the distiphallus. Scale: $0.5 \mathrm{~mm}$.

8.III.1988 (J.A. Rafael), 1 female (DZUP); Mato Grosso: Cáceres, 13.XI.1984 (C. Elias), 4 females (DZUP); Mato Grosso do Sul: Salobra, 18-20.X.1938 (MNRJ), 1 female; Rio de Janeiro: Petrópolis, 1.II.1956 (D.O. Albuquerque), 2 males, 2 females (all with puparia) (MNRJ); São Paulo: Santana do Parlamento, 20.VI.1984 (T. Schumaker), 2 females (DZUP); ibidem, 11.X.1984 (T. Schumaker), 1 female (DZUP); ibidem, 14.II.1984 (T. Schumaker), 1 female (DZUP); Atibaia, 1.IV.1983 
(D.Natal), 2 males (MZSP); Campinas, II.1990 (J. Mendes), 1 male, 2 females (DZUP); ibidem, XII.1990 (J. Mendes), 1 female (DZUP); Santa Catarina: Itajaí, 5.VII.1988 (C.G. Paloschi), 2 females (DZUP); ibidem, IX.1988 (C.G. Paloschi), 2 males, 3 females (DZUP); ibidem, X.1988 (C.G. Paloschi), 1 male, 1 female (DZUP); ibidem, XI.1988 (C.G. Paloschi), 2 males, 1 female (DZUP); ibidem, IX.1989 (C.G. Paloschi), 1 male (DZUP); ibidem, XI. 1989 (C.G. Paloschi), 6 males (DZUP); ibidem, I.1990 (C.G.Paloschi), 2 males, 1 female (DZUP); Seara (Nova Teutonia), XI.196 [sic] (F. Plaumann), 1 male (CNC); ibidem, VII.1969 (F. Plaumann), 1 male (CNC); Rio Grande do Sul: Quaraí, Estância S. Roberto, 1920.XI.1985 (J.R. Cure), 4 females (DZUP); ibidem, 21.XI.1985 (J.R. Cure), 1 male, 8 females (DZUP), ibidem, 22.XI.1985 (J.R. Cure), 1 female (DZUP). ARGENTINA, La Plata: Punta Lara, 13.I.1970 (Vardy \& Arguin-deguy), 5 males, 5 females (BMNH); Cordoba: Guanaca Muerto, III. 1977 (S.Bolle), 1 male, 2 females (CNC); Entre Rios: Liebig (Rio Uruguay), IV.1977 (S. Bolle), 3 males, 5 females (CNC); Buenos Aires: Rio Lujan, I.1977 (S. Bolle), 3 females (CNC); Jujuy, $15 \mathrm{~km} \mathrm{~S}$ of Jujuy, 1100 m, 20.X.1968 (L. Peña), 1 female (CNC); Catamarca: 18 km N La Merced., 1000 m, 26.IX.1968 (L.Peña), 1 female (CNC).

\section{Brontaea delecta (Wulp, 1896)}

Figs $5,10,15,20,25,29,34,44-46,51$

Limnophora delecta Wulp, 1896: 325.

Limnophora delecta; Stein, 1911: 135. - Stein, 1919: 134 (cat.). - Séguy, 1937: 262 (cat.).

Limnophora arcuata Stein, 1898: $201 \& 285$.

Limnophora arcuata; Coquillett, 1900: 256. - Howard, 1900: 582. - Stein, 1904: 469. - Stein, 1911:

135. - Stein, 1918: 235. - Stein, 1919: 133 (cat.). - Wolcott, 1924: 226. - Curran, 1928: 91. -

Séguy, 1937: 260 (cat.). - Wolcott, 1948: 495.

Limnophora? robusta Stein, 1901: 207, nomen nudum.

Eulimnophora arcuata; Malloch, 1920: plate 4, figs 17-18 (male genitalia).

Gymnodia arcuata; Huckett, 1965b: 884 (cat.). - Pont, 1972: 24 (cat.). - Huckett, 1975: 47.

Gymnodia delecta; Pont, 1972: 24 (cat.). - Linhares, 1981: 231.

Brontaea quadristigma; Skidmore, 1985: 431. - Mendes \& Linhares, 1993: 290 (Brazil). - Carvalho et al., 1993: 86 (cat.) [misidentifications].

This species was previously known as $B$. arcuata, but $B$. delecta has proved to be an older name for the species.

Types: Syntypes 1 male 1 female of Limnophora delecta are in the BMNH. The male is herewith designated as lectotype; it is labelled "Amula, / Guerrero, / $6000 \mathrm{ft}$. / Aug. H.H. Smith". The left mid leg and left hind leg are missing, otherwise it is in good condition. The female is here designated as paralectotype; it is labelled "Rincon, / Guerrero, / 2800 ft. / Oct. H.H. Smith]"; it is in good condition and is conspecific with the male.

The syntypes male and female of Limnophora arcuata from USA, Georgia [actually Tifton] and Louisiana were not seen. Some from Tifton are in USNM and FMNH and were seen by HUCKETT (1975). Note that specimens from Louisiana are also syntypes (STEIN 1898: 285). Further syntypes should be in ZMHU, where Stein's personal collection is located. 

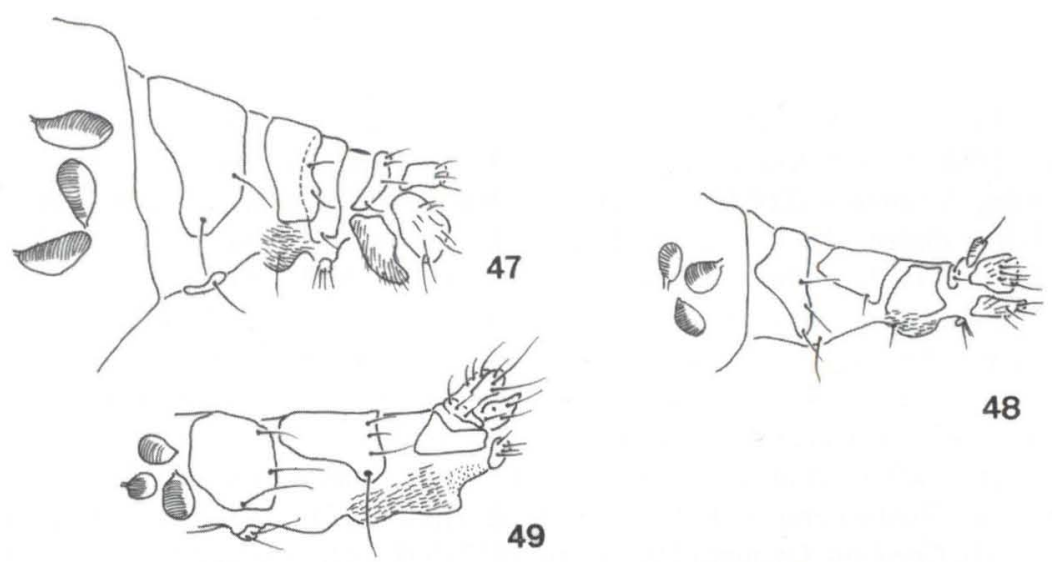

48
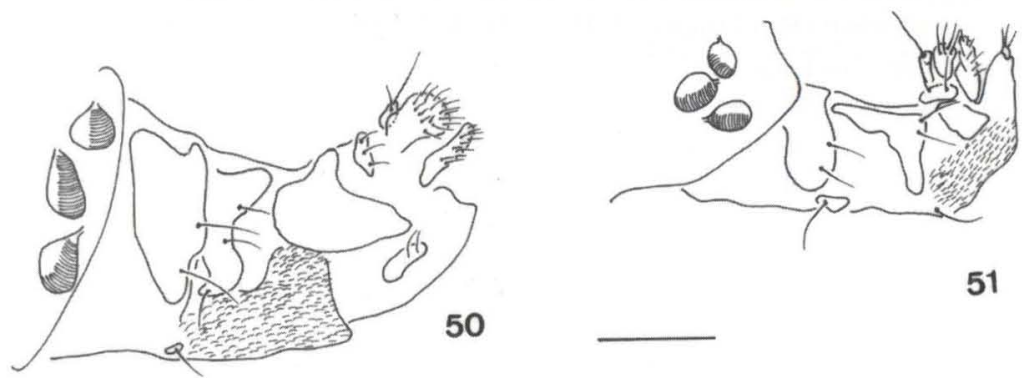

51

Figs 47-51. Ovipositor, lateral view, of Brontaea species. (47) debilis; (48) quadristigma; (49) humilis; (50) normata; (51) delecta. Scale $=0.25 \mathrm{~mm}$.

The female labelled as Limnophora? robusta, which STEIN (1901) mentioned in his report on Walker types, is in the BMNH and was also seen by HUCKETT (1972). It is dirty and damp, but appears to be a female of $B$. delecta.

Diagnosis. $B$. delecta can be distinguished from the other New World Brontaea species by the black palpi, black abdomen, and pattern of dark markings on scutum and abdomen (Figs 5, 10, 15, 20). The male distiphallus has spines in basal part (Figs 45, 46).

Description. Male. Head. Frons slender, at narrowest point almost obliterated and visible only as a seam. Eyes with only the normal pubescence, upper inner facets enlarged as usual but not conspicuously so. Ocellar seta very strong, at least as long as lowest frontal setae. Fronto-orbital plate, parafacial, face and gena silvery-white, more grey on lower part of head. Lunula yellowish, silvery-white pollinose. Frontoorbital plates slender, at lunula each one equal to just over diameter of anterior ocellus. 5-7 pairs of strong inclinate frontals on lower half of frons. Antenna black; flagellomere 2.5 times as long as broad, in frontal view, falling short of epistoma by 0.3 of its length. Parafacial linear, opposite insertion of arista equal to a little over diameter of anterior ocellus; not sunken. Parafacial and gena bare. Gena below lowest eye margin slightly narrower than width of antennal flagellomere. Prementum of proboscis short, dark brown dusted. Palpi dark brown, slender. 
Thorax. Ground-colour black, entirely dull grey dusted. Scutum with extensive brown dust forming a variable pattern of 3 vittae, which may be partly, mainly or wholly fused together on prst and most of post area; median vitta continuing broadly or narrowly on to scutellum (Fig. 5). Mesothoracic spiracle yellowish and metathoracic dark brown. Acr $0: 1$; prst setulae in 4 rows, outer rows at suture closer to de than to each other (Fig. 25); post setulae in 4-5 rows. 2 strong pprn, sa 1:1, ia $1: 2$, anterior post ia setose and at least twice as long as a ground-setula, 2 pa. 2 subequal npl setae. Anterior and lower ktps fine. Scutellum with 1 strong pair of apical and subbasal lateral setae; disc with setulae, these not descending below level of the strong setae, bare laterally and ventrally.

Legs. Black, knees narrowly yellow. Tarsi unremarkable. Fore femur with complete rows of PV, P and PD setae. Fore tibia without submedian setae. Mid femur with 5 strong PV setae in basal half, not equal to femoral depth; basal half with 7-9 A setae. Hind femur with 3-4 AV setae in apical half (Fig. 29); AD row complete; $1 \mathrm{D}$ and $0 \mathrm{PD}$ preapical setae. Hind tibia with 1 submedian AV seta subequal to median $\mathrm{AD}$.

Wings. Rather smoky, veins yellow to light brown. Membrane entirely covered with microtrichia. Tegula and basicosta dark brown. Crossvein $\mathrm{r}-\mathrm{m}$ placed below the point where vein $R_{1}$ enters costa. Crossvein dm-cu oblique, weakly curved. Upper calypter creamy, lower calypter deeper yellow. Halteres yellow.

Abdomen. Black in ground-colour. In posterior view densely light grey dusted; tergite $1+2$ only narrowly dark at base, mostly dusted; tergites 3 and 4 with the dark markings L-shaped, sometimes tending to be quadrate; tergite 5 with 1-2 pairs of diffuse oval brown marks (Fig. 10). Tergites without strong setae.

Genitalia. See figures 34, 44-46. 14 dissections.

Measurements $(\mathrm{n}=2)$. Length of body, 4.6-5.3 mm. Length of wings, 4.2$4.9 \mathrm{~mm}$.

Female. Differs from the male as follow:

Head. Frons broad, broadening gradually from vertex to lunula, at lunula 0.38-0.40 of maximum head-width. Upper inner eye facets not at all enlarged. Incurved vti and outcurved vte strong, subequal; pvt fine, outcurved. Fronto-orbital plates, parafacial, face and gena grey pollinose, the former conspicuously brownish along inner margin and at vertex. Frontal vitta matt black. Frontal triangle grey dusted, not quite reaching to lunula. Fronto-orbital plate quite broad, broadening gradually from vertex to lunula, at vertex a plate equal to twice diameter of anterior ocellus, at lunula broader than width of antennal flagellomere. Frontal vitta broad, narrowing to lunula where it is as wide as a fronto-orbital plate. 5 pairs of inclinate frontals on lower $2 / 3$ of frons; 2 orbitals, directed backwards and slightly outwards; fronto-orbital plate with few setulae. Parafacial narrow, opposite insertion of arista equal to twice diameter of anterior ocellus, gradually tapering below.

Thorax. Scutum with the brown dust forming 3 narrow but distinct vittae (Fig. 15). Anterior post ia seta usually strong.

Wings. Clear. Both calypters creamy.

Abdomen. Densely grey dusted; tergite $1+2$ almost wholly dusted; tergites 3 and 4 with the brown markings larger and more quadrate (Fig. 20); with numerous large brown bristle-dots. Setae sparse and short. 
Ovipositor. See figure 51. 13 dissections.

Measurements $(n=4)$. Length of body, 3.6-5.2mm. Length of wings, 3.2$4.8 \mathrm{~mm}$.

Distribution. Throughout most of USA and south-east Canada (North Dakota to Quebec, south to California and Florida), Central and South America, Hawaii.

Biology. B. delecta has been collected on human faeces (SKIDMORE 1985). In Brazil it has also been collected on this substrate in São Paulo State.

Material examined. CANADA, Quebec: Gatineau Co., Lake Duncan, near Masham, 7-8.VIII.1979 (A.C. Pont), 1 female (BMNH); ibidem, in faeces trap, 7.VII.1991 (A.C. Pont), 1 male (BMNH), Ontario: Marmora, 16.VII.1952 (J.R. Vockeroth), 3 females (CNC); Midland, 2.V.1959 (J.G. Chillcott), 1 female (CNC); Ottawa, 23.VI.1957 (J.G. Chillcott), 1 female (CNC); Park Twp, Algona dist., 2.VII.1955 (P.D. Syme), 1 male, 1 female (CNC); Pele Island, 18.VI.1974 (D.M. Wood), 1 female (CNC). USA, Arkansas: Petit Jean R., S. Magazine, 17.III.1972 (H.J. Teskey), 1 female (CNC); California: Palm Springs, 23.II.1955 (J.E.H. Martin), 1 male (CNC); Illinois: Urbana, 23.XI.1913, 1 male (USNM); Florida: Archbold Biol, Station, Highlands Co., 23-26.IV.1967 (B.V. Peterson), 20 males, 12 females (CNC); Everglades City, Hwy 29, Collier Co., 1.V.1967 (B.V. Peterson), 1 female (CNC); Gulf Hammock, 23.IV.1952 (J.R. Vockeroth), 3 males, 6 females (CNC); Orlando, 17.III.1947, 18.iii.1947 (F.M. Snyder), 2 male, 1 female (BMNH); Palm Beach, III.1900, 1 female (BMNH); Prairie Cr., 14 miles S Arcadia, Desoto Co., 27.IV.1967 (B.V. Peterson), 2 males (CNC), Pennsylvania: Spring Br, 14.V.1945 (DDT Expt), 1 male (USNM); Georgia: Talbotton, 3.IV.1937 (P.W. Fattig.), 1 male (USNM); Addie Branch, E fork Chattooga River, Rabun Co., 2400 ft, 1.VIII.1957 (J.G. Chillcott), 1 female (CNC); Rabun Bald, Rabun Co., 4200 ft, 16.VII.1957 (J.G. Chillcott), 1 female (CNC). ?Indian River City, 19.II.1946 (F.M. Snyder), 1 female (BMNH); Louisiana: 11 miles SW Alexandria, 26.III.1960 (J.G. Chillcott), 2 females (CNC); Mamou, 28.III.1960 (J.G. Chillcott), 3 females (CNC); Oak Grove, 3 miles S, 31.III.1960 (J.G. Chillcott), 5 males, 9 females (CNC); Maryland: Catoctin Mountain Park, Owens Creek, 15.VI.1991 (A.C. Pont), 1 female, (BMNH); New York: berth beside outlet Cayuta Lake, 20.V.1965 (H.J. Teskey), 1 female (CNC). North Carolina: M. Mitchell, 22.V.1960 (H.C. Huckett), 1 male (USNM); Blue Ridge Pkwy, Mt Richmond-Balsam, 30.V.1965 (J.G. Chillcott), 1 male (CNC); Franklin, 2000 ft, 8.V.1957 (J.R. Vockeroth), 1 female (CNC); Highlands, 7.V.1957 (W.R.M. Mason), 1 female (CNC); Highlands, $3800 \mathrm{ft}$, 3-10.VI.1957 (J.R. Vockeroth), 3 females (CNC); Highlands, 14.VII.1957 (C.J. Durden), 6 females (CNC); Highlands, 3800 ft, 21.VIII.1957 (J.G. Chillcott, W.R. Richards), 2 females (CNC); Great Smoky Mt NP, Indian Gap, 5200 ft, 28.V.1957 (W.R.M.Mason), 1 female (CNC); Ohio: Amherst, VII-VIII.1958 (H.J. Reinhard), 1 female (CNC); Arizona: Tucson, reared, ex rotting Saguaro, 29.X.1960 (F.J. Santana), 1 male (USNM); Texas: Mened, 17.X-28.X.1929 (E.C.C. Coll.), 1 male (USNM); Mc Cook, 22.II.1979 (C. Newell), 1 male (USNM); Del Rio, 17.IX.1979 (B.Billman), 2 males (USNM); Big Bend NP, Dugout Wells, 3000 ft, 22.V.1959 (J.F. McAlpine), 1 male, 2 females (CNC); Big Bend NP, Spring Oak, 19.V.1959 (J.F. McAlpine), 1 male (CNC); College Station, Brazos Co., 3.IV.1968 (D.M. 
Wood), 1 male, 1 female (CNC); Dimmit Co., 16.III.1942, 1 female (CNC); Fredericksburg, 18.IV.1959 (J.F. McAlpine), 4 males (CNC); Kerrville, 28.III21.IV.1959 (J.F. McAlpine), 15 males, 3 females (CNC); La Grange, 7.IV.1959 (J.F. McAlpine), 1 male (CNC). Mexico: Chiapas, S. Crist. Ias Casas, $7200 \mathrm{ft}$, 1.VI.1969, 1 female (CNC); Chih., Majaica, 45 miles NW Chihuahua, $7000 \mathrm{ft}$, 29.V.1964 (J.F. McAlpine), 1 female (CNC); DF: Xochimilco, $8000 \mathrm{ft}$, 18.VIII.1962 (H.E.Milliron), I female (CNC); Durango, 24 miles W La Ciudad, 7000 ft, 28.VI.1964 (W.R.M. Mason), 1 male (CNC); ibidem, 25.VI.1964 (J.F. McAlpine), 1 female (CNC); Durango, 3 miles E El Salto, 8200 ft, 4.VII.1964 (J.F. McAlpine), 3 females (CNC); 8 miles E El Salto, 8200 ft, 23.VI.1964 (J.F. McAlpine), 1 female (CNC); 10 miles E El Salto, 9000 ft, 16.VI.1964 (J.F. McAlpine), 1 female (CNC); 10 miles W El Salto, 9000 ft, 28.VII.1964 (J.F. McAlpine), 1 female (CNC); Toluca, 22 miles N, 8800 ft, 17.VIII.1954 (J.G. Chillcott), 1 male (CNC); Sin., 8 miles W El Palmito, 6000 ft, 15.VII.1964 (J.F. McAlpine), 1 male (CNC). ST. LuCiA: Black Bay, 26.II-1.III.1978 (S.A. Marshall), 1 female (CNC); Castries, 16-26.II.1978 (S.A. Marshall), 2 males, 1 female (CNC); Piton Flore, 21.II.1978 (S.A. Marshall), 1 female(CNC). PERU, Tingo Maria: Huanuco, 800 m, 5-9.IV.1963 (L. Peña), 1 female (CNC); Trujillo, 10.IX.1949 (H.E. Box), 1 female, BMNH. BRAZIL, Rio Grande do Norte: Natal, 5-24.II.1943 (F.M. Snyder), 1 female (MNRJ); Bahia: Canudos, 7.IX.1951 (Travassos), 1 male (MNRJ); São Paulo: Campinas, II.1990 (J. Mendes), 2 females (DZUP). ARGENTINA, Buenos Aires: Buenos Aires (Olivos), XII.1977 (S.Bolle), 29 males (CNC); San Isidro, I. 1977 (S. Bolle), 2 females (CNC); Rio Lujan, I.1977 (S.Bolle) 1 female (CNC); Catamarca: $18 \mathrm{~km} \mathrm{~N}$ la Merced., 1000 m, 26.IX.1968 (L. Peña), 2 females (CNC); Entre Rios: Liebig (Rio Uruguay), IV. 1977 (S. Bolle), 1 male (CNC); Jujuy: 15 km S Jujuy, 1100 m, 20.X.1968 (L. Peña), 1 female (CNC); Tucuman, Ao. El Cajeo, W Alpachiri, 1000 m, 1.X.1968 (L. Peña), I female (CNC). Chile, Curico: Estero la Jaula, I.1964 (L. Peña), 1 female (CNC).

\section{Brontaea humilis (Zetterstedt, 1860)}

Figs $3,8,13,18,23,32,40,41,49$

Aricia humilis Zetterstedt, 1860: 6221.

Gymnodia humilis; Huckett, 1965b: 884 (cat.).

Brontaea humilis; Skidmore, 1985: 434.

Type. Holotype male from Lule Lappmark, Sweden, in NRS (RINGDAHL 1918: 159; 1939: 149) [not seen].

Diagnosis. B. humilis can be distinguished from the other New World Brontaea species by the strong anterior post ia seta and, in the male, by the dark brown non-vittate scutum, smoky brown calypters and sunken parafacials.

Description. Male. Head. Frons slender, at narrowest point almost obliterated and visible only as a seam. Eyes with only the normal pubescence, upper inner facets enlarged as usual but not conspicuously so. Ocellar setae very short, not much longer than length of ocellar tubercle. Fronto-orbital plate, parafacial, face and gena silvery-white, more grey or even tinged with brown on lower part of head. Lunula 
yellowish, silvery-white pollinose. Fronto-orbital plates slender, at lunula each one equal to diameter of anterior ocellus. 6-7 pairs of short inclinate frontals on lower $1 / 3$ of frons. Antenna black; flagellomere 2.6 times as long as broad, in frontal view falling short of epistoma by 0.3 of its length. Parafacial linear, opposite insertion of arista less than diameter of anterior ocellus; sunken and, in profile, obscured by eye. Parafacial and gena bare. Gena below lowest eye-margin 0.6 width of antennal flagellomere. Prementum of proboscis short, dark brown dusted. Palpi black, slender.

Thorax. Ground-colour black. Scutum and scutellum dark brownish-grey dusted (Fig. 3), mostly shining black outside ia; pleura wholly grey dusted. Mesothoracic spiracle yellowish and metathoracic dark brown. Acr 0:1; prst setulae in 4 rows, outer rows at suture closer to each other than to dc (Fig. 23); post setulae in 4 rows. 2 strong pprn, sa 1:1, ia 1:2, prst ia fine, 2 pa. 2 subequal npl setae. Anterior and lower ktps fine. Scutellum with 1 strong pair of apical and subbasal lateral setae; disc with setulae, these not descending below level of the strong setae, bare laterally and ventrally.

Legs. Black. Tarsi unremarkable. Fore femur with complete rows of PV, P and PD setae. Fore tibia without submedian setae. Mid femur with 3 strong PV setae in basal half, not equal to femoral depth. Hind femur with 2-3 AV bristles in apical third (Fig. 28); AD row complete; with $1 \mathrm{D}$ and 0 PD preapical setae. Hind tibia with 1 short submedian AV seta subequal to median AD.

Wings. Rather smoky, veins light brown. Membrane entirely covered with microtrichia. Tegula black, basicosta orange to brown. Crossvein $r-m$ placed before the point where vein $\mathrm{R}_{1}$ enters costa. Crossvein $\mathrm{dm}$-cu oblique, sinuous. Calypters smoky brown (paler in immature specimens). Halteres yellowish.

Abdomen. Black in ground-colour. Densely grey dusted, in posterior view the dusting appearing almost silvery; tergite $1+2$ black, with a dusted hind-margin; tergites 3 and 4 with the dark markings quadrate; tergite 5 with a pair of dark oval spots (Fig. 8). Tergites without strong setae.

Genitalia. See figures 32, 40-41. 2 dissections.

Measurements $(n=5)$. Length of body, 4.1-4.4mm. Length of wing, 3.9$4.2 \mathrm{~mm}$.

Female. Differs from the male as follow:

Head. Frons broad, broadening gradually from vertex to lunula, at lunula 0.44 of maximum head-width. Upper inner eye-facets not at all enlarged. Incurved vti and outcurved vte strong, subequal; pvt fine, outcurved. Fronto-orbital plate, parafacial, face and gena grey pollinose, the former commonly brown along inner edge. Frontal vitta matt black. Frontal triangle grey dusted, extending at least halfway to lunula. Fronto-orbital plate quite broad, broadening gradually from vertex to lunula, at vertex a plate just over diameter of anterior ocellus, at lunula equal to width of antennal flagellomere. Frontal vitta broad, narrowing to lunula where it is slightly broader than a fronto-orbital plate. 3-4 pairs of inclinate frontals on lower half of frons; 2 orbitals, directed backwards and slightly outwards; fronto-orbital plate with few setulae. Parafacial slender, opposite insertion of arista 
equal to twice diameter of anterior ocellus, gradually tapering below.

Thorax. Scutum, scutellum and pleura wholly grey dusted; scutal vittae distinct but weakly marked (Fig. 13), the median vitta sometimes extending on to scutellum.

Wings. Clear, veins yellow. Calypters creamy.

Abdomen. Densely grey dusted; tergite $1+2$ partly to mostly grey, otherwise brown; tergites 3 to 5 with the dark markings quadrate, larger than in male, almost reaching sides on tergites 3 and 4 (Fig. 18). Setae sparse and short.

Ovipositor. See figure 49.3 dissections.

Measurements. Length of body, 3.0-4.3mm [n=25]. Length of wing, 3.1$4.4 \mathrm{~mm}(\mathrm{n}=25)$.

Distribution. Most of Central and North Europe, eastwards through $\mathrm{Pa}$ laearctic Asia to North China and Japan (Hokkaido) (PONT 1986). In North America only from Michigan (HucketT 1965b), North Carolina, Ontario, Quebec and British Columbia. The species was not known in North America when HuCKETT (1932) revised the Limnophora-group of genera, and its introduction from Europe into the New World probably postdates this paper. Huckett did not include the genus in his review of northern Nearctic Muscidae (HUCKETT 1965a).

Biology. Adults are attracted to horse dung, in which the larvae breed, and also to honeydew on foliage and not infrequently to light traps (see SKIDMORE 1985). In Europe the species is well known to overwinter as an adult, sometimes coming into houses in enormous numbers. To judge by label data on the material before us, its behaviour is identical in Ottawa, Canada.

The species was also described by HeNNIG (1959: 248-249), and the male genitalia were illustrated by COLLIN (1930: figure 25 on plates 17 and 24).

Material examined. CANADA, British Columbia: Gagnon Road, 6 miles W of Terrace, 29.VI.1960 (C.H. Mann), 1 male (CNC); Ontario: Bell's Cor., 2.V.1951 (J.F. McAlpine), 1 female, (CNC); Blackburn, 23.VI.1952 (J.F. McAlpine), 1 female (CNC); Blackburn, Mer Bleue, 27.VI.1955 (J.F. McAlpine), 1 female (CNC); Constance Bay, 1.X.1953 (J.F. McAlpine), 1 female (CNC); Ottawa, 22.IV.1948 (A.R. Brooks), 1 female (BMNH); Marmora, 4.IX.1952 (J.F. McAlpine), 1 female (CNC); Maynooth, 2.VII.1951 (J.F. McAlpine), 1 female (CNC); Ottawa, attic window, 3.III.1951 (J.F. McAlpine), 1 female (CNC); Ottawa, 27.III. 1952 (J.F. McAlpine), 2 females (CNC); Ottawa, 28.X.1954 (J.F. McAlpine), 2 females (CNC); Ottawa, 19.XI.1954 (G.S. Walley), 7 females (CNC); Ottawa, at window in house, 27.I.1955 (J.F. McAlpine), 1 female (CNC); Ottawa, 6.XI.1955 (J.R. Vockeroth), 1 female (CNC); Ottawa, $18 . I V .1958$ (J.F. McAlpine), 3 females (CNC); Ottawa, 15.VII.195 [sic] (J.E.H. Martin), 1 female (CNC); Ottawa, 6.III. 1966 (G.S. Walley), 1 female (CNC); Ottawa, Rockcliffe, McKay Lake, 27.IV.1955 (J.F. McAlpine), 2 females (CNC); ibidem, 20.IV.1955 (J.F. McAlpine), 1 female (CNC); Perth Road, 11.XI.1951 (J.R. Vockeroth), 1 male (CNC); Quebec: Beech Grove, 15.V.1951 (J.F. McAlpine), I female (CNC); ibidem, 5.X.1951, 1 male, 1 female (CNC). USA; North Carolina: Highlands, 3800 ft, 29.V.1957 (J.R. Vockeroth), 1 male (CNC). 
Brontaea humilis is most likely to confused with $B$. quadristigma, which is also a small dark species. $B$. humilis has a long anterior post ia seta, whereas in $B$. quadristigma this seta is reduced and barely longer than a ground-setula. Moreover, the male of $B$. humilis has the scutum dark brown dusted, without vittae, the parafacials sunken, and the calypters smoky brown, whilst the female has the frons strikingly broader and the fronto-orbital plate dull grey to brownish-grey pruinose.

\section{Brontaea normata (Bigot, 1885)}

Figs $4,9,14,19,24,33,42,43,50$

Limnophora normata Bigot, 1885: 272. - Stein, 1904: 468. - Stein, 1907: 280. - Stein, 1911: 136. Stein, 1918: 235. - Stein, 1919: 134, 135 (cat.). - Séguy, 1937: 266 (cat.).-Garcia, 1964: no page. - Pont, 1972: 29 (cat.).

Brachiophyra effrons Giglio-Tos, 1893: 9. - Wulp, 1896: 324.

Liminophora auctilus Stein, 1901: 187.

Gymnodia auctila; Pont, 1972: 24 (cat.).

Brontaea normata; Carvalho et al., 1993: 86 (cat.)

Types. Lectotype male of Limnophora normata from "Mexique", in UMO [by designation of A.C. Pont in CARVAlHo et al. 1993].

Syntypes malefemale of Brachiophyra effrons from Tuxpango, Mexico, in IMZ [not seen].

Holotype male of Limnophora auctilus from "Brasilien", in BMNH. It is in poor condition, with right fore leg and all middle and hind legs missing; it is very dirty and wet. The name auctilus was an unpublished Walker name that Stein mentioned in his account of the Walker types and which he validated by an accompanying description. We have dissected the genitalia of this male and can confirm the synonymy with $B$. normata.

Diagnosis. $B$. normata can be distinguished from the other New World Brontaea species most simply by scutal pattern, with the 3 black vittae strong, very distinct, and well defined (Figs 4, 14).

Description. Male. Frons slender, at narrowest point almost obliterated and visible only as a seam. Eyes with only the normal pubescence, upper inner facets enlarged as usual but not conspicuously so. Ocellar setae strong. Fronto-orbital plate, parafacial, face and gena silvery-white, more grey on lower part of head. Lunula yellowish, silvery-white pollinose. Fronto-orbital plates slender, at lunula each one slightly broader than diameter of anterior ocellus. 5-8 pairs of short inclinate frontals on lower half of frons. Antenna black; flagellomere over 2.6 times as long as broad, in frontal view falling short of epistoma by 0.7 of its length. Parafacial linear, opposite insertion of arista equal to diameter of anterior ocellus; not sunken. Parafacial and gena bare. Gena below lowest eye margin slightly less than width of antennal flagellomere. Prementum of proboscis short, dark brown dusted. Palpi black, slender.

Thorax. Ground-colour black, entirely yellowish-grey dusted. Scutum with 3 strong, distinct, and well-defined vittae, extending from neck and on to scutellum, the median one narrower than the paramedian pair (Fig. 4). Mesothoracic spiracles yellowish and metathoracic dark brown. Acr 0:1; prst setulae in 4 rows, outer rows 
at suture equidistant between dc and each other (Fig. 24); post setulae in 4-5 rows. 2 strong pprn, sa $1: 1$, ia 1:1, anterior post ia reduced to a setula, 2 pa. 2 subequal npl setae. Anterior and lower ktps fine. Scutellum with 1 strong pair of apical and subbasal lateral setae; disc with setulae, these not descending below level of the strong setae, bare laterally and ventrally.

Legs. Black. Tarsi unremarkable. Fore femur with complete rows of PV, P and PD setae. Fore tibia without submedian setae. Mid femur with 4-5 short PV setae in basal half, not equal to femoral depth; 7-9 fine A setae in basal half. Hind femur with 2-3 AV setae in apical third; AD row complete; with $1 \mathrm{D}$ and 0 PD preapical setae. Hind tibia with 1 submedian AV seta subequal to median AD.

Wings. Clear to weakly smoky, veins yellow. Membrane entirely covered with microtrichia. Tegula black, basicosta orange to brown. Crossvein r-m placed just before point where vein $\mathrm{R}_{1}$ enters costa. Crossvein dm-cu oblique, weakly curved. Calypters creamy, margins yellow. Halteres yellowish-white.

Abdomen. Ground-colour mainly yellow, base of tergite 1+2, part of tergite 4 and all of tergite 5 black. In posterior view, densely yellowish-white dusted, almost pale golden; tergite $1+2$ with only hind-margin dusted; tergites 3 and 4 each with a pair of black L-shaped markings; tergite 5 generally with 2 pairs of dark diffuse spots (Fig. 9). Tergites without strong setae.

Genitalia. See figures 33, 42-43. 3 dissections.

Measurements $(n=7)$. Length of body, $3.9-5.1 \mathrm{~mm}$. Length of wings, 4.1-5.3mm.

Female. Differs from the male as follow:

Head. Frons broad, broadening gradually from vertex to lunula, at lunula 0.39 of maximum head-width. Upper inner eye facets not at all enlarged. Incurved vti and outcurved vte strong, subequal; pvt fine, outcurved. Fronto-orbital plate, parafacial, face and gena grey pollinose. Frontal vitta matt black. Frontal triangle brownish-grey dusted, reaching almost to lunula. Fronto-orbital plate quite broad, broadening gradually from vertex to lunula, at vertex a plate just over diameter of anterior ocellus, at lunula equal to width of antennal flagellomere. Frontal plate broad, narrowing to lunula where it is slightly broader than a fronto-orbital plate. 5-6 pairs of inclinate frontals on lower $2 / 3$ of frons; 2 orbitals, directed backwards and slightly outwards; fronto-orbital plate with few setulae. Parafacial slender, opposite insertion of arista equal to twice diameter of anterior ocellus, gradually tapering below. 14).

Thorax. Scutum with the vittae not always extending on to scutellum (Fig.

Wings. Clear. Calypters creamy, including margins.

Abdomen. Entirely black in ground-colour. Tergites with dense grey dust, tinged with yellowish posteriorly; tergite $1+2$ with a small black spot basally and two elongate transverse marks; tergites 3 and 4 each with two small spots in basal part and two larger transverse marks apically, these sometimes connected to form L-shaped markings, larger and better defined than in male; tergite 5 with two pairs of black spots, the basal pair smaller and sometimes absent (Fig. 19). Setae sparse and short.

Ovipositor. See figure 50. 3 dissections. 
Measurements $(\mathrm{n}=43)$. Length of body, $3.6-4.6 \mathrm{~mm}$. Length of wings, 3.8 $-4.8 \mathrm{~mm}$.

Distribution. Widespread but uncommon throughout the Neotropical region, nowhere abundant: Mexico, Venezuela, Colombia, Peru, Bolivia, Brazil, Paraguay.

Biology. Adults have been collected in Brazil on fresh cow dung, together with $B$. quadristigma and $B$. debilis, suggesting that the larvae of $B$. normata also breed in this substrate.

Material examined. MeXICO: Chiapas, Jct. Hwys 190-200, 7.VI.1969 (B.V. Peterson), 1 male (CNC). Peru, Madre de Dios: Avispas, 400 m, 10-20.IX.1962 (L. Peña), 4 females (CNC); ibidem, 20-30.IX.1962, 3 females (CNC); Junin: Chanchamayo, 2.VIII.1948 (J.M. Schunke), 1 male (MNRJ); Tingo Maria: Huanuco, 800 m, 5-9.IV.1963 (L. Peña), 1 female (CNC). BRAzIL, Bahia: Salvador, 18.VII.1951 (L. Carlos), 1 female (MNRJ); Rio de Janeiro: Petrópolis, Alto da Mosela (Albuquerque), 1 male, 1 female (MNRJ); Santa Catarina: Itajaí, 15.IX.1988 (C.G. Paloschi), 1 female (DZUP); ibidem, XI.1988 (C.G. Paloschi), 1 female (DZUP); ibidem, XII.1988 (C.G. Paloschi), 2 males, 7 females (DZUP); ibidem, I.1989 (C.G. Paloschi), 1 female (DZUP); ibidem, II.1989 (C.G. Paloschi), 1 male, 1 female (DZUP); ibidem, IV.1989 (C.G. Paloschi), 1 male, 4 females (DZUP); ibidem, IV.1989 (C.G. Paloschi), 1 male, 4 females (DZUP); ibidem, V.1989 (C.G. Paloschi), 1 female (DZUP); ibidem, VI.1989 (C.G. Paloschi), 1 male, 1 female (DZUP); ibidem, VII.1989 (C.G. Paloschi), 1 female (DZUP); ibidem, XI.1989 (C.G. Paloschi), 2 females (DZUP); ibidem, XII.1989 (C.G. Paloschi), 5 females (DZUP); ibidem, III.1990 (C.G.Paloschi), 1 female (DZUP); ibidem, IV.1990 (C.G. Paloschi), 4 females (DZUP).

Immature adults of $B$. normata may be confused with $B$. debilis, which can also have the black scutal vittae rather well developed, but $B$. normata has wholly black palpi (mostly yellow in B. debilis) and wholly black knees, especially in female (broadly yellow in debilis).

\section{Brontaea quadristigma (Thomson, 1869)}

Figs $2,7,12,17,22,27,31,37-39,48$

Anthomyia quadristigma Thomson, 1869: 551.

Limnophora quadristigma; Stein, 1910: 67. - Stein, 1919: 137 (cat.), - Séguy, 1937: 268 (cat.).

Eulimnophora cilifera Malloch, 1920: 145, syn.n..

Limnophora cilifera; Huckett, 1932: 55. - Séguy, 1937: 261 (cat.).

Gymnodia cilifera; Huckett, 1965b: 884 (cat.). - Huckett, 1975: 48. - Wharton \& Moon, 1979: 85.

Brontaea cilifera; Skidmore, 1985: 432. - Blume, 1986: 220. - Mendes \& Linhares, 1993: 290 (Brazil). - Carvalho et al., 1993: 85 (cat.). - Woodley \& Hilburn, 1994: 35 (Bermudas).

Brontaea sp.; Carvalho \& Couri, 1992: 37.

Limnophora tetrastigma, error.

This species has previously been known as $B$. cilifera, but $B$. quadristigma has proved to be an older name.

Types: The holotype male of Anthomyia quadristigma, from "Puna" [=Guayaquil Bay, Ecuador], is in NRS. It is labelled "Puna."; "Kinb." [the collector 
Kinborg]; "Typus". It is not in good condition; left mid leg, both hind legs, and most of right wing missing. The apical part of the abdomen has been removed, and the genitalia dissected; they are stored in glycerine in a microvial pinned alongside the holotype.

Holotype male of Eulimnophora cilifera from Waukegan, Illinois, is in INHS and was probably seen by HUCKETT (1975) and was listed by WEBB (1980: 89) [not seen].

Diagnosis. B. quadristigma is the smallest New World Brontaea species (apart from the very restricted $B$. humilis). The male can be most reliably distinguished by the shape of the cercal plate (Fig. 37). External characters are enumerated in the key.

Description. Male. Head. Frons slender, at narrowest point almost obliterated and visible only as a seam. Eyes with only the normal pubescence, upper inner facets enlarged as usual but not conspicuously so. Ocellar setae very short, hardly longer than length of ocellar tubercle. Fronto-orbital plate, parafacial, face and gena silvery-white, more grey on lower part of head. Lunula yellowish, silvery-white pollinose. Fronto-orbital plates slender, at lunula each one equal to diameter of anterior ocellus. 3-4 pairs of short inclinate frontals on lower 1/3 of frons. Antenna black; flagellomere 2.6 times as long as broad, in frontal view falling short of epistoma by 0.3 of its length. Parafacial linear, opposite insertion of arista equal to the diameter of anterior ocellus; sunken and in profile partly obscured by eye. Parafacial and gena bare. Gena below lowest eye margin about half width of antennal flagellomere. Prementum of proboscis short, dark brown dusted. Palpi black, slender.

Thorax. Ground-colour black, entirely grey dusted. Scutum with weak indications of 3 broad brownish vittae, the median one only rarely continuing on to scutellum (Fig. 2). Mesothoracic spiracle creamy and metathoracic pale brownish. Acr $0: 1$; prst setulae in 4 rows, outer rows at suture much closer to dc than to each other (Fig. 22); post setulae in 4 rows. 2 strong pprn, sa 1:1, ia 1:2, anterior post ia only a little longer than a ground-setula, 2 pa. 2 subequal npl setae. Anterior and lower ktps fine. Scutellum with 1 strong pair of apical and subbasal lateral setae; disc with setulae, these not descending below level of the strong setae, bare laterally and ventrally.

Legs. Black, knees narrowly yellow. Tarsi unremarkable. Fore femur with complete rows of PV, P and PD setae. Fore tibia without submedian setae. Mid femur with a row of 5-7 strong PV setae in basal half, not quite equal to femoral depth, continuing as a series of setulae; 6-7 fine A setae in basal half. Hind femur with 3-4 strong AV setae in apical third, preceded by a series of much shorter but distinct setae along basal part of this surface (Fig. 27); AD row complete; with $1 \mathrm{D}$ and 0 PD preapical setae. Hind tibia with 1 short submedian AV seta subequal to median AD.

Wings. Clear, veins yellow. Membrane entirely covered with microtrichia. Tegula dark brown, basicosta orange to brown. Crossvein $\mathrm{r}-\mathrm{m}$ placed below the point where vein $\mathrm{R}_{1}$ enters costa. Crossvein dm-cu oblique, straight. Calypters creamy, margins yellowish. Halteres creamy. Abdomen. Black in ground-colour. 
Densely grey dusted in posterior view, sometimes weakly tinged with yellow; tergite $1+2$ black with a dusted hind-margin; tergites 3 and 4 with the dark markings quadrate; tergite 5 with or without a pair of dark oval spots (Fig. 7). Tergites without strong setae.

Genitalia. See figures 31, 37-39. 15 dissections.

Measurements $(n=19)$. Length of body, $3.0-3.9 \mathrm{~mm}$. Length of wings, 2.8 $-3.7 \mathrm{~mm}$.

Female. Differs from the male as follows:

Head. Frons broad, broadening slightly from vertex to lunula, at lunula 0.37-0.40 of maximum head-width. Upper inner eye facets not at all enlarged. Ocellar setae strong. Incurved vti and outcurved vte strong, vte shorter than vti; pvt fine, outcurved. Fronto-orbital plate, parafacial, face and gena grey pollinose, the former often brownish at vertex. Frontal vitta matt black. Frontal triangle grey dusted, extending almost to lunula. Fronto-orbital plate quite broad, broadening gradually from vertex to lunula, at vertex a plate almost twice diameter of anterior ocellus, at lunula rather less than width of antennal flagellomere. Frontal vitta broad, narrowing to lunula where it is almost twice as broad as a fronto-orbital plate. 3-4 pairs of inclinate frontals on lower $2 / 3$ of frons; 2 orbitals, directed backwards and slightly outwards; fronto-orbital plate with very few setulae. Parafacial slender, opposite insertion of arista equal to diameter of anterior ocellus, gradually tapering below.

Thorax. Scutum with the brown vittae rather more distinct (Fig. 12).

Legs. Mid femur with the PV setae shorter and weaker. Hind femur without AV except for the 2-3 setae before apex.

Wings. Margins of calypters creamy.

Abdomen. Densely grey dusted; tergite 1+2 dusted only on hind-margin; tergites 3 and 4 with the dark markings large and quadrate; tergite 5 with a pair of oval spots, sometimes divided transversely into 2 pairs (Fig. 17). Setae sparse and short.

Ovipositor. See figure 48.6 dissections.

Measurements $(\mathrm{n}=27)$. Length of body, $2.6-3.6 \mathrm{~mm}$. Length of wings, 2.4 $-3.4 \mathrm{~mm}$.

Distribution. Widespread through the southern US states from California to Florida, with its northern limit in Missouri, Kansas, Virginia. Guadeloupe, Bermuda, West Indies. Also widespread in South America, though only recently recognised there.

Biology. Reared only from cow dung (SKIDMORE 1985). For additional details, see also WHARTON \& MOON (1979) and BLUME (1986).

Material examined. USA, South Dakota: Brookings, 25.VIII.1924, 1 male (USNM); Arizona: Portal, 17.VIII.1965 (H.J. Reinhard), 1 female (CNC); Florida: Archbold Biol. Station, Highlands Co., 23-26.IV.1967 (B.V. Peterson), 13 males (CNC); Ft Ogden, 9.IV.1952 (J.R. Vockeroth), 6 males, 5 females (CNC); Gainesville, 26.IV.1952 (O. Peck), 1 male (CNC); Gulf Hammock, 23.IV.1952 (O. Peck, J.R. Vockeroth), 1 male, 1 female (CNC); North Carolina: Highlands, 21.VIII.1957 
(W.R. Richards), 1 female (CNC); Texas: Brazos Co., College Station, cow dung, 15-17.VII. 1984 (R. Blume), 1 male, 1 female (BMNH); Davis Mts St. Pk., 5200 ft, 19-22.VII.1973 (E. Lindquist), 3 males (CNC). MeXICO: Chiapas, 10 miles N Bochil, 11.VI.1969 (H.J. Teskey), I male (CNC); Chiapas, San Cristobal, 15.VII. 1969 (D. Kritsch), 1 male (CNC); Chiapas, San Cristobal de Las Casas, $7087 \mathrm{ft}$, 12-13.VI. 1969 (B.V. Peterson), 2 females (CNC); ibidem, 7200 ft, 17.VI.1969 (W.R.M. Mason), 1 female (CNC); Chiapas, 3 miles NE San Cristobal, 8.VI.1969 (B.V. Peterson), 1 male (CNC); Chiapas, 32 miles W San Cristobal, Jct 190-195 Hwys, 11.VI.1969 (H.J. Teskey), 1 female (CNC); Chiapas, 20-25 miles N Huixtla, 3000 ft, 4.VI. 1969 (H.J. Teskey), 1 female (CNC); Chiapas, 10 km S Ocozocoautla, 3000-4000 ft, 2.VIII.1962 (H.E. Milliron), 1 female (CNC); Chiapas, Yerba Buena Hwy 195, 24.VI.1969 (B.V. Peterson), I female (CNC); Durango, 6500 ft, VIII. 1964 (J.F. McAlpine), 1 female (CNC); Durango, 5 miles W Durango, $6500 \mathrm{ft}$, 22.VII.1964 (J.F. McAlpine), 1 male (CNC); Guerrero, 22 miles N Chilpancingo, 24.VIII.1958 (H.F. Howden), 1 male (CNC); Guerrero, 8 miles S Iguala, 22.VIII. 1958 (H.F. Howden), 2 males (CNC); Ixtapan, LA Sal, 5500 ft, 9.VIII.1954 (J.G. Chillcott), 1 female (CNC); Morelos, Cuernavaca, 12 miles E, 4300 ft, 14.VIII.1954 (J.G.Chillcott), 1 male (CNC); N.L., 5 miles S Monterrey, 13.VII.1963 (H. \& A. Howden), 1 male (CNC); S.L.P., Xilitla, 14 miles W, 4200 ft, 22.VII.1954 (J.G. Chillcott), 1 female (CNC); Veracruz, Lake Catemaco, 15.VI.1969 (B.V. Peterson), 8 males, 3 females (CNC). Honduras, San Marcos: Chol., 29.VII.1958 (Neff \& Matthews), 1 male, 6 females (CNC). GuAdEloupe, Basse Terre: Col des Mamelles, 1.II.1987 (K.A. Spencer), 1 male (NMWC). GRENADA: Balthazar (Windward side), no date (H.H.Smith), 1 male (BMNH). HAITI: reared from cow dung (Myers), 1 male (BMNH); Kenscoff (Myers), 1 female (BMNH). DominicaN REPUBLIC: La Combre (P. Plata), 21-24.III.1978 (L. Masner), 6 males, 4 females (CNC); 100 km N Santo Domingo, 14.II.1978 (S.A. Marshall), 9 males, 3 females (CNC). JAMAICA: Mandeville, 23.X.1970 (J.H. Frank), 1 male, 3 females (MNRJ). ST. LuCiA: Black Bay, 26.II-1.III.1978 (S.A. Marshall), 1 male (CNC); Castries, 16-26.II.1978 (S.A. Marshall), 2 males (CNC). ST. VINCENT: Majorca, $1500 \mathrm{ft}$, VII-VIII.1972 (A.D. Harrison), 1 male (CNC). ST. MARTIN: Paradise Peak, 11.II.1978 (S.A. Marshall), 1 female (CNC). TRINIDAD: Manzanilla, x.1959, 1 female (CNC); Mt Lambert, 15.II.1961 (N. Gopaul), 1 female (CNC); ibidem, 13.V.1961 (N. Gopaul), 1 male (CNC); Mucurapo, 22.II.1961 (N. Gopaul), 1 male, 1 female (CNC); Piarco, VII.1959, 1 male (CNC). ECUADor, Napo: Coca, Napo R., 250 m, 25-30.IV.1965 (L. Peña), 1 female (CNC); Imbatura, Lago San Pablo, 2700 m, 2.VI.1977 (W. Schacht), 1 female (BMNH); S. Pedro - Zarumard, Loja, 850-1100 m, 9.IV.1965 (L.Peña), 1 female (CNC); Pichincha: Sto Domingo, 600 m, 19.VI.1965 (L.Peña), 1 female (CNC). ColomBiA: Leticia, 20-26.II.1972 (A. Sauvé), 1 female (CNC); Turbo, 2.VI.1943 (F.M.Snyder), 1 male (MNRJ). PERU, Cuzco: Quincemil, 780 m, 13-31.VIII.1962 (L. Peña), 8 males, 3 females (CNC); ibidem, $700 \mathrm{~m}, 1$ 1-15.XI.1962 (L. Peña), 1 male (CNC); ibidem, $740 \mathrm{~m}, 27-$ 31.VIII.1962 (L. Peña), 3 females (CNC); ibidem, 760 m, 15-30.X.1962 (L. Peña), 1 female (CNC); ibidem, 740 m, VIII. 1962 (L. Peña), 1 female (CNC); Tingomaria, Huanuco, 800 m, 5-9.IV.1963 (L. Peña), 1 male (CNC). BoliviA, La Paz: Santa Barbara, N. Coroico, Yungas, 1100 m, 4-5.I.1976(L.Peña), 1 male, 1 female (CNC). 
BRAZIL, Roraima: Ilha de Maracá, (Rio Uraricoera), 2-13.V.1987 (Rafael, Brasil \& Aquino), 1 male (DZUP); Minas Gerais: Lassance, 20-31.I.1939 (Martins, Lopes \& Mangabeira), 2 males, 2 females (MNRJ); Rio de Janeiro: Petrópolis, Alto da Mosela, 1-II/8.III.1957 (D.O. Albuquerque), 1 male (MNRJ); Rio de Janeiro, VII, 1 male (BMNH); São Paulo: Santana do Parlamento, 20.V.1985 (T.Schumaker), 1 female (DZUP); Santa Catarina: Itajai, IX. 1988 (C.G. Paloschi), 2 males, 1 female (DZUP); ibidem, X.1988 (C.G. Paloschi), 2 males, 17 females (DZUP). Rio Grande do Sul: Quaraí, Estância S. Roberto, 19-20.XI.1985 (J.R. Cure), 1 male (DZUP); ibidem, 21.XI.1985 (J.R. Cure), 4 males, 2 females (DZUP). ARGENTINA, Buenos Aires: (Rio Lujon), I. 1977 (S. Bolle), 2 males, 3 females (CNC); Catamarca, $18 \mathrm{~km}$ N La Merced., 1000 m, 26.IX.1968 (L. Peña), 1 female (CNC); Entre Rios, Liebig (Rio Uruguay), IV.1977 (S. Bolle), 15 males, 9 females (CNC); La Plata: Punta Lara, 13.I.1970 (Vardy \& Arguin-deguy), 2 males, 2 females (BMNH); Tucuman: Ao. El Caleo, W Alpachiri, 1000 m, 1.X.1968 (L. Peña), 1 male (CNC); Tucuman, Arroyo, 14 km S El Tala, 700 m, 13-14.X.1968 (L. Peña), 4 males (CNC).

In many features the male is similar to $B$. humilis, which also has the parafacial sunken and the ocellar setae short, but $B$. quadristigma has the anterior post ia very reduced and the scutum mostly grey dusted. Both sexes are difficult to separate from $B$. delecta, and all the characters given in the key should be checked.

ACKNOWLEDGEMENTS. We are most grateful to the collection managers of the institutions listed in the introduction for enabling us to study material in the collections under their care. This paper was completed whilst ACP was on a scientific exchange at the Universidade Federal do Paraná, Curitiba, Brazil, and for this the support of the British Council and of $\mathrm{CNPq}$ (grant \# 450.099/96-2) is gratefully acknowledged.

\section{REFERENCES}

ALDRICH, J.M. 1905. A catalogue of North American Diptera (or two-winged flies). Smithson. misc. Collns 1444: 1-680.

Bigot, J.M.F. 1885. Diptères nouveaux ou peu connus. $25^{\mathrm{e}}$ partie. XXXIII. Anthomyzides nouvelles. Annls Soc. ent. Fr. (6) 4: 263-304 [1884].

BLUME, R.R. 1986. Parasites of Diptera associated with bovine droppings on a pasture in east central Texas. Southwest Entomol. 11: 215-222.

Capriles, J.M. \& C.A. Navarro. 1971. Additions and corrections to Wolcott's "Insects of Puerto Rico". Caribb. Jour. Sci. 7: 45-64.

CARvalho, C.J.B. DE. 1989. Classificação de Muscidae (Diptera): uma proposta através da análise cladística. Revta bras. Zool. 6: 627-648.

Carvalho, C.J.B. DE \& M.S. Couri. 1992. Muscidae, Fanniidae e Calliphoridae (Diptera) do Projeto Maracá, Roraima, Brasil. Acta Amazonica 21: 35-43.

Carvalho, C.J.B. De; M.S. Couri; A.C. Pont; D. Pamplona \& S.M. Lopes. 1993. Part II, Muscidae. In: C.J.B. DE CARvalho (Ed.). A Catalogue of the Fanniidae and Muscidae (Diptera) of the Neotropical Region. São Paulo, Sociedade Brasileira de Entomologia, $201 \mathrm{p}$.

Collin, J.E. 1930. A revision of the Greenland species of the anthomyid genus 
Limnophora sens. lat. (Diptera), with figures of the male genitalia of these and many other Palaearctic species. Trans. ent. Soc. Lond. 78: 255-281.

CoquilletT, D.W. 1900. Report on a collection of dipterous insects from Puerto Rico. Proc. U.S. natn. Mus. 22: 249-270.

1910. The type-species of the North American genera of Diptera. Proc.

U.S. natn. Mus. 37: 499-647.

Curran, C.H. 1928. Insects of Porto Rico and the Virgin Islands. Diptera or Two-winged Flies. In: Scientific Survey of Porto Rico and the Virgin Islands, New York, 11 (1): 1-118.

. 1938. New American Diptera. Amer. Mus. Novit. 975: 1-7.

Garcia, P.C. 1964. Moscas de Venezuela. Caracas, 17p.

Giglio-Tos, E. 1893. Diagnosi di nuovi generi e di nuove specie di Ditteri. VIII.

Boll. Musei Zool. Anat. comp. R. Univ. Torino 8 (147): 1-11.

Gregor, F. 1975. Synanthropy of Anthomyiidae, Muscidae and Calliphoridae

(Diptera) in Cuba. Folia parasit. 22: 57-71.

HenNiG, W. 1959. Muscidae [Part, Lieferung 204]. In: E. LINDNER (Ed.). Die

Fliegen der palaearktischen Region, Stuttgart, 63b: 233-288.

HowARD, L.O. 1900. A contribution to the study of the insect fauna of human excrement. Proc. Wash Acad. Sci. 2: 541-604.

HucketT, H.C. 1932. The North American species of the genus Limnophora

Robineau-Desvoidy, with descriptions of new species (Muscidae, Diptera) [Part.]. Jour. N.Y. ent. Soc. 40: 25-76.

- 1965a. The Muscidae of Northern Canada, Alaska and Greenland (Diptera). Mem. ent. Soc. Can. 42: 1-369.

- 1965b. Muscidae, p. 869-915. In: A. Stone; C.W. Sabrosky; W.W. WirTh; R.H. FoOTE \& J. COUlson (Eds). A Catalog of the Diptera of America North of Mexico. U.S. Dep. Agric. Agric. Handbook (276): 1-1696.

- 1972. Francis Walker's little known North American specimens of the families Anthomyiidae and Muscidae (Diptera) in the British Museum (Natural History). Ent. News 83: 169-172.

-1975. The Muscidae of California exclusive of subfamilies Muscinae and Stomoxyinae. Bull. Calif. Insect Surv. 18: 1-148.

KowARZ, F. 1873. Beitrag zur Dipteren-Fauna Ungarns. Verh. zool.-bot. Ges. Wien 23: $453-464$.

LinHares, A.X. 1981. Synanthropy of Muscidae, Fanniidae and Anthomyiidae

(Diptera) in the city of Campinas, São Paulo, Brazil. Revta bras. Ent. 25: 231-243.

Malloch, J.R. 1920. Descriptions of New North American Anthomyiidae (Diptera). Trans. Amer. ent. Soc. 46: 133-196.

MCALPINE, J.F. 1981. Morphology and terminology, p.9-63. In: J.F. MCALPINE;

B.V. Peterson; G.E. Shewell; H.J. Teskey; J.R. Vockeroth \& D.M.Wood (Eds). Manual of Nearctic Diptera 1. Res. Branch Agric. Canada, Ontario, Monograph 27: 1-674.

MENDES, J. \& A.X. LinharES. 1993. Atratividade por iscas, sazonalidade e desen- 
volvimento ovariano em várias espécies de Muscidae (Diptera). Revta bras. Ent. 37: 289-297.

PonT, A.C. 1972. A Catalogue of the Diptera of the Americas South of the United States. 97. Family Muscidae. São Paulo, Museu de Zoologia, $111 \mathrm{p}$. . 1977. The Australian and some other species of Gymnodia Robineau-Desvoidy (Diptera: Muscidae). Aust. Jour. Zool. 25: 347-369. 1986. Family Muscidae. In: Á. Soós \& L. PAPP (Eds). Catalogue of Palaearctic Diptera 11. Budapest, Akadémiai Kiadó, 346p.

RINGDAHL, O. 1918. Neue nordische Anthomyiden. Ent. Tidskr. 39: 148-194. 1939. Diptera der Fam. Muscidae (die Gattungen Aricia und Anthomyza) von Zetterstedt in "Insecta Lapponica" und "Diptera Scandinaviae" beschrieben. Opusc. Ent. 4: 137-159.

ROBERTS, R.A. 1934. Some Insects collected in Mexico, mostly in association with man and animals or animal products. Jour. N.Y. ent. Soc. 42: 249-262.

ROBINEAU-DESVOIDY, A.J.B. 1863. Histoire naturelle des Diptères des environs de Paris. Oeuvre posthume du $\mathrm{D}^{\mathrm{r}}$ Robineau-Desvoidy publiée par les soins de sa famille, sous la direction de M. H. Monceaux. Paris, Masson, Leipzig, Vol. 2, p.1-920.

SÉGUY, E. 1937. Diptera Fam. Muscidae. In: P. WyTSMAN (Ed.). Genera Insectorum, Bruxelles, 205: 1-604.

SKIDMORE, P. 1985. The biology of the Muscidae of the world. Series ent., 29: $1-550$.

STEIN, P. 1898. Nordamerikanische Anthomyiden. Beitrag zur Dipterenfauna der Vereinigten Staaten. Berl. ent. Z. 42: 161-288 [1897]. Sammlung des British Museum zu London (Dipt.). Z. syst. Hymenopt. Dipterol. 1: 185-221.

1904. Die amerikanischen Anthomyiden des Königlichen Museums für Naturkunde zu Berlin und des Ungarischen National-Museums zu Budapest. Annls hist.-nat. Mus. natn. hung. 2: 414-495.

1907. Revision der Bigot'schen und einiger von Macquart beschriebenen aussereuropäischen Anthomyiden (Dipt.). [Part.] Z. syst. Hymenopt. Dipterol. 7: 273-293

1910. Die von Thomson beschriebenen Anthomyiden der Eugenies Resa. Wien. ent. Ztg 29: 66-78.

1911. Die von Schnuse in Südamerika gefangenen Anthomyiden. Arch. Naturgesch. 77 (1): 61-189.

. 1918. Zur weitern Kenntnis aussereuropäischer Anthomyiden. Annls hist.-nat. Mus. natn. hung. 16: 147-244.

. 1919. Die Anthomyidengattungen der Welt, analytisch bearbeitet, nebst einem kritisch-systematischen Verzeichnis aller aussereuropäischen Arten. Arch. Naturgesch., 83 (1): 85-178 [1917].

Thomson, C.G. 1869. Diptera. Species nova descripsit. In: Kongliga svenska fregatten Eugenies Resa omkring jorden under befäl af C.A. Virgin, ären 
1851-1853. Stockholm, Norstedt Zoologi, Part 2, p.443-614.

WeBB, D.W. 1980. Primary insect types in the Illinois Natural History Survey collection, exclusive of the Collembola and Thysanoptera. Bull. Ill. nat. Hist. Surv. 32: 51-191.

Wharton, R.A. \& R.D. Moon. 1979. Puparia of cyclorrhaphous Diptera from bovine dung in open pasture and rangeland in the transition zone of western North America. Ann. ent. Soc. Amer. 72: 80-89.

Williston, S.W. 1896. On the Diptera of St. Vincent (West Indies). Trans. ent. Soc. Lond.: 253-446.

WolCOTT, G.N. 1924. "Insectae Portoricensis". A preliminary annotated check-list of the insects of Porto Rico, with descriptions of some new species. Jour. Dep. Agric. P. Rico 7: 1-313.

Wolcott, G.N. 1948. The Insects of Puerto Rico. Diptera. Jour. Agric. Univ. P. Rico 32: 417-532.

Woodley, N.E. \& D.J. Hilburn. 1994. The Diptera of Bermuda. Contr. Amer. ent. Inst. 28 (2): 1-64.

WUlP, F.M. VAN DER. 1896. Group Anthomyinae. [Part.] In: F.D. GODMAN \& O.

SAlvin (Eds). Biologia Centrali-Americana. Zoologia-Insecta-Diptera. London, Taylor \& Francis, part 132, p.321-344.

ZetTERSTEDT, J.W. 1860. Diptera Scandinaviae disposita et descripta. [Part.] Tomus decimus qvartus seu ultimus, continens addenda, corrigenda $\&$ emendanda tomis prioribus, una cum indice alphabetico novarum speciarum hujus $\&$ praecedentis tomi, atque generico omnium tomorum. Lundae [=Lund], ex officina lundbergiana, p.6191-6609. 